\title{
Modeling of Soil Losses on a Yellow Argisol Under Planted Forest
}

\author{
Danielle Vieira Guimarães ${ }^{1}$ (D), Marx Leandro Naves Silva ${ }^{1}$, Nilton Curi ${ }^{1}$, \\ Ricardo Previdente Martins ${ }^{2}$, José de Oliveira Melo Neto ${ }^{3}$ \\ ${ }^{1}$ Universidade Federal de Lavras - UFLA, Lavras/MG, Brasil \\ ${ }^{2}$ Suzano Papel e Celulose, Teixeira de Freitas/BA, Brasil \\ ${ }^{3}$ Universidade Federal do Tocantins - UFT, Gurupi/TO, Brasil
}

\begin{abstract}
Erosion prediction models are a useful tool for soil use planning and soil conservation. This study aimed to apply the Universal Soil Loss Equation (USLE) in an experimental sub-basin located in the municipality of Teixeira de Freitas, in the southern end of the state of Bahia, Brazil. The following variables were calculated: rainfall erosivity factor, using the precipitation data; soil erodibility factor, by the correlation between erosivity and soil losses obtained from a standard plot installed in the field; topographic factor; vegetation cover and management factor; and conservation practices factor. The product of these factors corresponded to the soil losses in the sub-basin. Data from erosion plots were used to validate the model. The USLE predicted higher soil losses than that observed in the plots, and the eucalyptus proved to be efficient at reducing soil losses by erosion.
\end{abstract}

Keywords: water erosion, USLE, GIS, eucalyptus. 


\section{INTRODUCTION}

Changes in the soil use without proper management may cause soil susceptibility to erosive agents. Water erosion is the most active form of soil degradation, and soil loss rate may exceed soil replacement rate (Eduardo et al., 2013; Ribeiro et al., 2016). Measures to prevent environmental and economic damage due to erosion must be adequately developed to ensure their efficiency.

In this sense, the planning of conservation practices to be adopted in plant production systems must aim at expanding the productive capacity and rationality regarding soil use and conservation (Rampim et al., 2012).

The knowledge about erosive processes of a watershed, considered as basic planning unit, is crucial for soil use planning (Oliveira et al., 2012). Water erosion prediction models are key tools to identify areas affected or subject to erosive processes, besides favoring the understanding of these processes and evaluating possible causes and effects (Santos et al., 2006).

Such models are advantageous for allowing fast evaluation of several scenarios and for being inexpensive. In addition, they assist in preventing environmental degradation by erosion and controlling erosion processes already underway (Machado et al., 2003).

Erosive process modeling has significantly improved since the 1950s with the creation of the Universal Soil Loss Equation (USLE), which is the most widely used erosion prediction model in the world to calculate the mean annual erosion rate for different soils and climatic conditions (Mello et al., 2016; Silva et al., 2016). The USLE has undergone a positive change due to the technological advance, such as the Revised Universal Soil Loss Equation (RUSLE), making them the most common mathematical water erosion prediction models (Cecílio et al., 2009; Ozcan et al., 2015)

Amorim et al. (2010) highlight the importance of studies that evaluate and validate soil loss prediction models for Brazilian conditions since most of them were developed for temperate regions. According to the authors, the few studies carried out in Brazil considered only the application of the models, without effectively validating them.
The association between soil loss prediction models and Geographic Information Systems (GIS) has been very useful to improve results. GIS allows extrapolating useful information to soil use planning by means of treatment, analysis, and data modeling (Silva et al., 2013).

One of the main reasons for using GIS is that erosional processes vary spatially. Moreover, GIS enable planners to quantify soil losses at different scales (Avanzi et al., 2013).

Therefore, this study aimed to apply and validate the USLE model in a sub-basin in the municipality of Teixeira de Freitas, southern end of the state of Bahia, Brazil.

\section{MATERIAL AND METHODS}

The study was carried out in the southern end of the state of Bahia, in an experimental sub-basin (199.49 ha) belonging to the Itanhém River Basin, located in the municipality of Teixeira de Freitas (Figure 1), East Atlantic Hydrographic Region. The region has climate type Af, according to the Köppen classification (Peel et al., 2007), characterized by hot and humid tropical climate, with average monthly temperatures above $22{ }^{\circ} \mathrm{C}$. The soil throughout the sub-basin is classified as Yellow Argisol (EMBRAPA, 2013). The region is cover by native forest (sub-perennial tropical forest) and eucalyptus plantation, with the presence of areas without vegetation cover.

Soil loss was estimated by the USLE, proposed by Wischmeier \& Smith (1978), as follows (Equation 1):

$A=R * K * L * S * C * P$

where $\mathrm{A}$ is the soil loss $\left(\mathrm{Mg} \mathrm{ha}^{-1}\right.$ year $\left.^{-1}\right)$; $\mathrm{R}$ is the rainfall erosivity factor ( $\mathrm{MJ} \mathrm{mm} \mathrm{ha-1} \mathrm{h}^{-1}$ year $\left.{ }^{-1}\right)$; is the soil erodibility factor $\left(\mathrm{Mg} \mathrm{h} \mathrm{MJ}^{-1} \mathrm{~mm}^{-1}\right)$; LS is the topographic factor, dimensionless, which includes slope steepness (S) and slope length (L); C is the cover and management factor, dimensionless; and $\mathrm{P}$ is the conservation practice factor, dimensionless.

First, rainfall erosivity (R) was calculated by determining the erosivity index $\mathrm{EI}_{30}$, based on the methodology proposed by Wischmeier \& Smith (1978). Precipitation data were obtained from an automated meteorological station (Campbell ${ }^{\circledR}$, model CR10x), with a minimum precipitation equivalent to $0.2 \mathrm{~mm}$, 


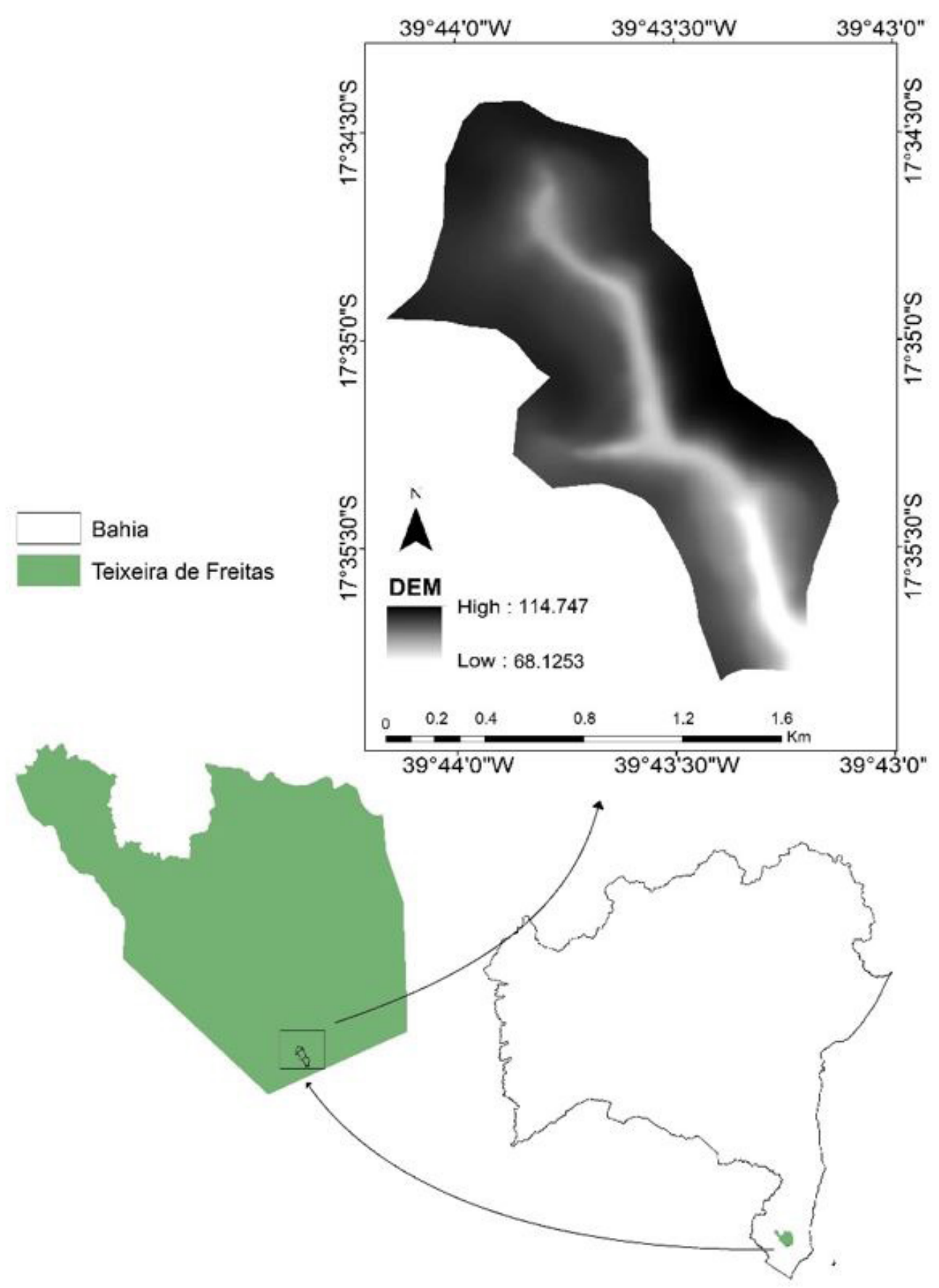

Figure 1. Location of the studied sub-basin, belonging to the Itanhém River Basin, in the municipality of Teixeira de Freitas, southern end of the state of Bahia, Brazil.

located in the evaluated area, with data recorded every 10 minutes, from 2010 to 2013.

Using the precipitation data, total kinetic energy of the precipitation and its maximum 30-min intensity $\left(\mathrm{I}_{30}\right)$ were calculated for each event. The rainfall erosivity index $\left(\mathrm{EI}_{30}\right)$ is the product between the $\mathrm{I}_{30}$ and the kinetic energy of the precipitation.

Soil erodibility factor was calculated by simple regression analysis between the monthly erosivity factor $(\mathrm{X})$ and the monthly soil loss $(\mathrm{Y})$, considering the 
linear equation. Thus, erodibility is the ratio between $\mathrm{X}$ and Y (McGregor et al., 1969). The LS factor of the plot (Equation 2) was considered in order to correct factor $\mathrm{K}$.

$L S=0.00984 * C^{0.63} * D^{1.18}$

where $\mathrm{D}$ is the angle of the slope, expressed in percentage; $\mathrm{C}$ is the slope length of the land, in meters; and LS is the topographic factor for the plot of soil loss.

To determine the topographic factor (LS) for the entire basin, a Digital Elevation Model with a $10 \mathrm{~m}$ resolution was generated from contour lines. The slope map was obtained (Figure 2) with a minimum value of $0.03 \%$ and a maximum value of $5.32 \%$.
Slope length considered the pixel size, as shown in Equation 3, proposed by Renard et al. (1997):

$$
L=\left(\frac{\lambda}{22.13}\right)^{m}
$$

where $\lambda$ is the cell size and $\mathrm{m}$ is the slope length exponent, given by Equation 4:

$$
m=\frac{\beta}{1+\beta}
$$

in which $\beta$ considers the rill and interrill erosion and the slope angle $(\theta)$, according to Equation 5 (McCool et al., 1989):

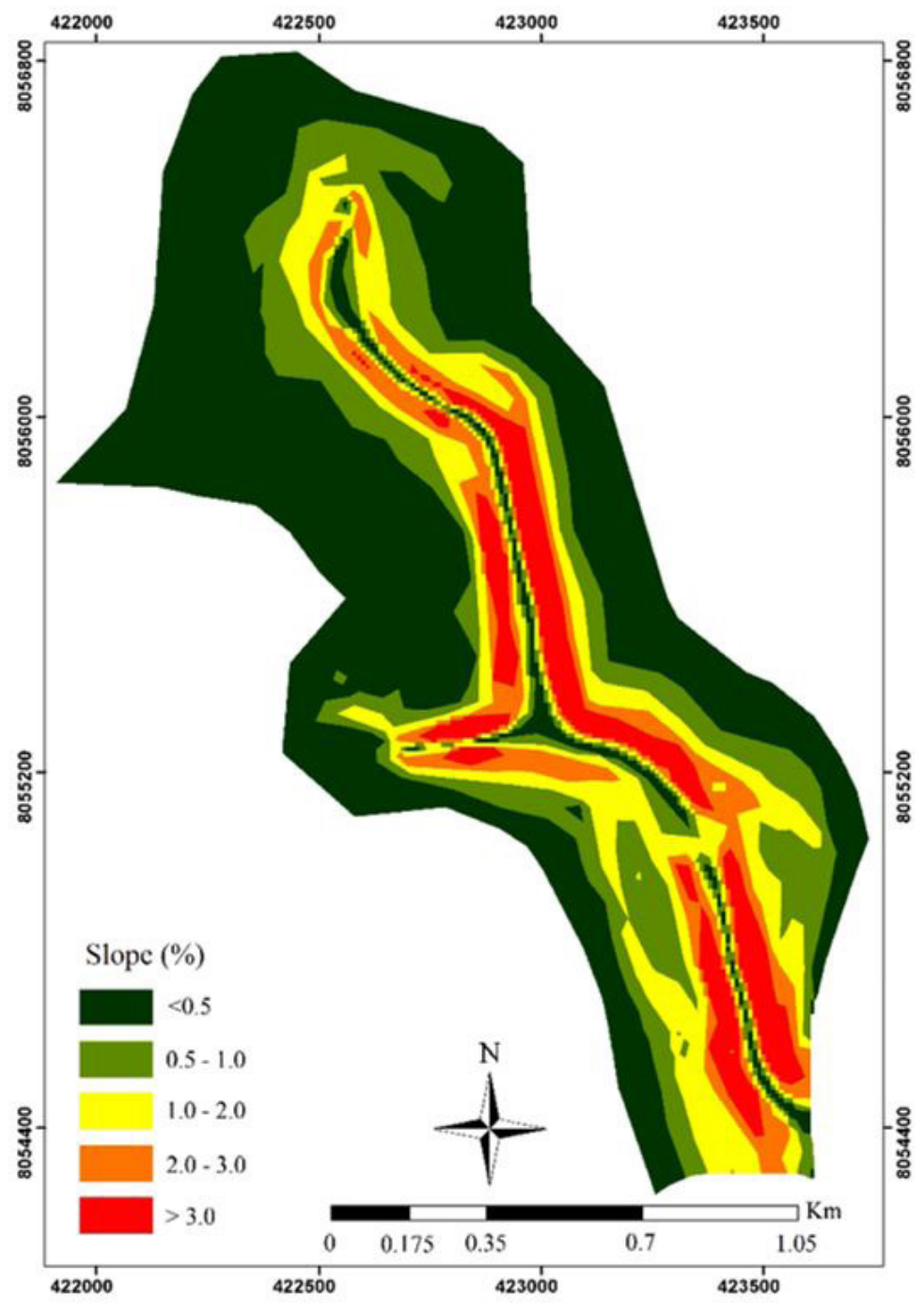

Figure 2. Slope map of the sub-basin, in the municipality of Teixeira de Freitas, southern end of the state of Bahia, Brazil. 


$$
\beta=\frac{\frac{\operatorname{sen} \theta}{0.0896}}{\left(3 *(\operatorname{sen} \theta)^{0.8}+0.56\right)}
$$

Slope steepness (S) was obtained based on McCool et al. (1987), expressed by Equations 6 and 7:

$$
\begin{aligned}
& S=10.8 * \operatorname{sen} \theta+0.03 \quad(\text { steepness }<9 \%) \\
& S=16.8 * \operatorname{sen} \theta-0.50 \quad(\text { steepness } \geq 9 \%)
\end{aligned}
$$

Bertoni \& Lombardi (2012) stated that the cover and management factor is the ratio between soil loss from an area with specified vegetation cover and the soil loss from an area without vegetation cover (USLE standard plot). Thus, factor C was calculated based on the methodology proposed by Wischmeier (1960), by initially determining the soil loss ratio (SLR) for each vegetation cover of the sub-basin, according to Equation 8:

$$
S L R_{i}=\frac{\sum_{i=1}^{n} S L_{c}}{\sum_{i=1}^{n} S L_{d}}
$$

where $\mathrm{SL}_{c}$ is the soil loss of the area with vegetation cover, and $\mathrm{SL}_{\mathrm{d}}$ is the loss in the USLE standard plot. Additionally, the study considered the relation between rainfall erosivity at each cropstage $\left(\mathrm{R}_{\mathrm{i}}\right)$ and the total erosivity of the evaluated period $\left(\mathrm{R}_{\mathrm{t}}\right)$, resulting in the erosivity index fraction in 30 minutes (EIF30), as shown in Equation 9:

$$
\mathrm{EIF}_{30}=\frac{\sum_{\mathrm{i}=1}^{\mathrm{n}} \mathrm{Ri}}{\mathrm{Rt}}
$$

Finally, factor C is the product of $\operatorname{SLR}_{1}$ and $\mathrm{EIF}_{30}$. This factor was calculated for both vegetation covers evaluated in this study. The factor $\mathrm{C}$ obtained for eucalyptus referred to the18-month-old plant (postplanting stage). The soil use map of the sub-basin (Figure 3), obtained by the RapidEye Imagery with a spatial resolution of $5 \mathrm{~m}$ and sensors that capture data in the blue, green, red, red-edge, and next infrared spectral bands, was used for the spatialization of this factor. The image used to obtain the soil use map was classified by the Nearest Neighbor Classifier, in the eCognition software.

The conservation practice factor $(\mathrm{P})$ is the ratio between the soil loss with a conservation practice and the soil loss in a downhill cultivation (Bertoni \& Lombardi, 2012). The implementation of the eucalyptus culture did not follow the level of the land. Therefore, the calculation considered a value of $\mathrm{P}$ equal to 1 for the whole sub-basin, based on Bertoni \& Lombardi (2012).

To validate the model, this study considered the soil loss data collected from October 2012 to March 2014 , from plots installed in the sub-basin in an area under native forest, eucalyptus, and uncovered soil, based on the methodology proposed by Cogo (1978). The soil loss modeling was performed in the ArcGIS ${ }^{\circledR}$ software (version 10.1).

\section{RESULTS AND DISCUSSION}

The $\mathrm{EI}_{30}$ of the region between 2010 and 2013 was 3,438.21 MJ mm ha ${ }^{-1} \mathrm{~h}^{-1}$ year-1, ranging from $1,136.24$ to $5,245.37 \mathrm{MJ} \mathrm{mm} \mathrm{ha}^{-1} \mathrm{~h}^{-1}$ year $^{-1}$, while total annual precipitation ranged from $845.4 \mathrm{~mm}$ to $1,267.0 \mathrm{~mm}$, with an average of 1,098.57 $\mathrm{mm}$ (Figure 4).

Trindade et al. (2016) evaluated the spatial distribution of factor $\mathrm{R}$ in Brazil and obtained values ranging from 2,000 to $14,000 \mathrm{MJ} \mathrm{mm} \mathrm{ha}{ }^{-1} \mathrm{~h}^{-1}$ year $^{-1}$ in the East Atlantic Basin, and estimated values between 8,000 and $10,000 \mathrm{MJ} \mathrm{mm} \mathrm{ha}{ }^{-1} \mathrm{~h}^{-1}$ year $^{-1}$ in the same region of the present study area. This estimate shows that the erosivity determined in the present study showed low to medium values for the $\mathrm{R}$ factor, besides being below the estimated value of the mentioned authors. This fact emphasizes the importance of studies on erosivity for each region since precipitation has a high spatial variability.

In the tropics, precipitation is the most influential climatic factor for soil erosion due to the volume and time and space distribution (Machado et al., 2013). Martins et al. (2010a), in a study in Aracruz, state of Espírito Santo (a region close to the present study area), observed a variation between years from 4,536 to $17,056 \mathrm{MJ} \mathrm{mm} \mathrm{ha}^{-1} \mathrm{~h}^{-1}$ year ${ }^{-1}$, reinforcing the knowledge of the great variability of the precipitation behavior in the region.

$\mathrm{EI}_{30}$ has been proven to be an adequate index to express rainfall erosivity in regions with similar climatic characteristics to those found in Brazil. According to Martins et al. (2010a), $\mathrm{EI}_{30}$ has been widely used by several Brazilian researchers, providing good correlations with soil loss. 


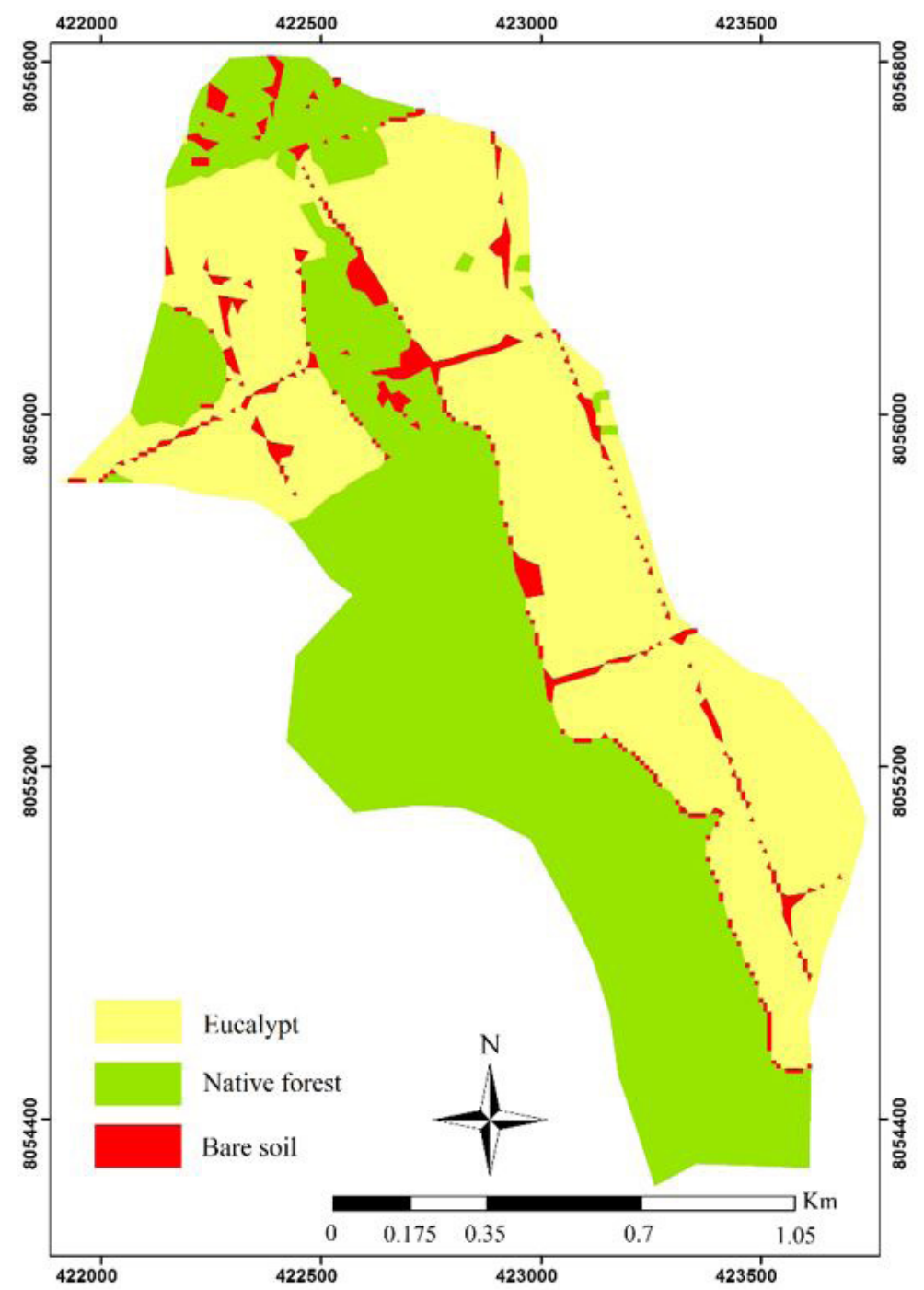

Figure 3. Soil use map of the sub-basin in the municipality of Teixeira de Freitas, southern end of the state of Bahia, Brazil.

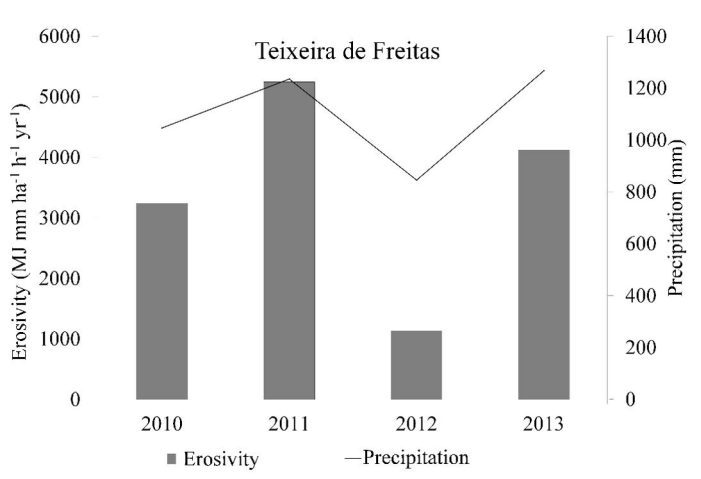

Figure 4. Precipitation and rainfall erosivity for the municipality of Teixeira de Freitas, southern end of the state of Bahia, Brazil.
Soil erodibility (factor $\mathrm{K}$ ) determined for the Yellow Argisol was $0.14 \mathrm{Mg} \mathrm{h} \mathrm{MJ}^{-1} \mathrm{~mm}^{-1}$, after correction by the LS factor. The Pearson's coefficient determined for the relation between soil loss and erosivity was 0.52 , indicating intermediate positive correlation (Camargo \& Sentelhas, 1997).

The value found for factor $\mathrm{K}$ is considered as high. A study performed by Martins et al. (2011) in soils of the Coastal Tablelands, in the same region of the present study area, showed a value of $\mathrm{K}$ equal to $0.007 \mathrm{Mg} \mathrm{h} \mathrm{MJ}^{-1} \mathrm{~mm}^{-1}$ for Yellow Argisol, considering the entire culture cycle. Based on Silva et al. (2015), soils of this region are mainly derived from sediments 
from the Barreiras Formation, and its most outstanding characteristic is the presence of cohesive subsurface horizons, which favors soil susceptibility to erosion by hindering the water movement in the soil profile.

The short collection time of the present study, i.e., only 18 months of observation, resulted in high values. Thus, a larger database is necessary for better representativeness.

Additionally, the first months of data collection were affected by soil changes provided by the plot installation, such as soil disruption, consequently influencing soil susceptibility to erosion processes.
The topographic factor ranged from 0.03 to 3.1 (Figure 5). LS values in 5.4 and $79 \%$ of the study area were greater than 2 and lower than 1, respectively. Avanzi et al. (2013) stated that higher values of LS might increase runoff volume and kinetic energy, consequently potentiating soil losses. Accordingly, Oliveira et al. (2010) affirmed that high values of LS could cause greater surface runoff, favoring water erosion.

Factor $\mathrm{C}$ was 0.005 for both the eucalyptus and native forest equations, reflecting the high soil loss observed in the area without vegetation cover, which received a value of vegetation cover index equal to 1 . The values

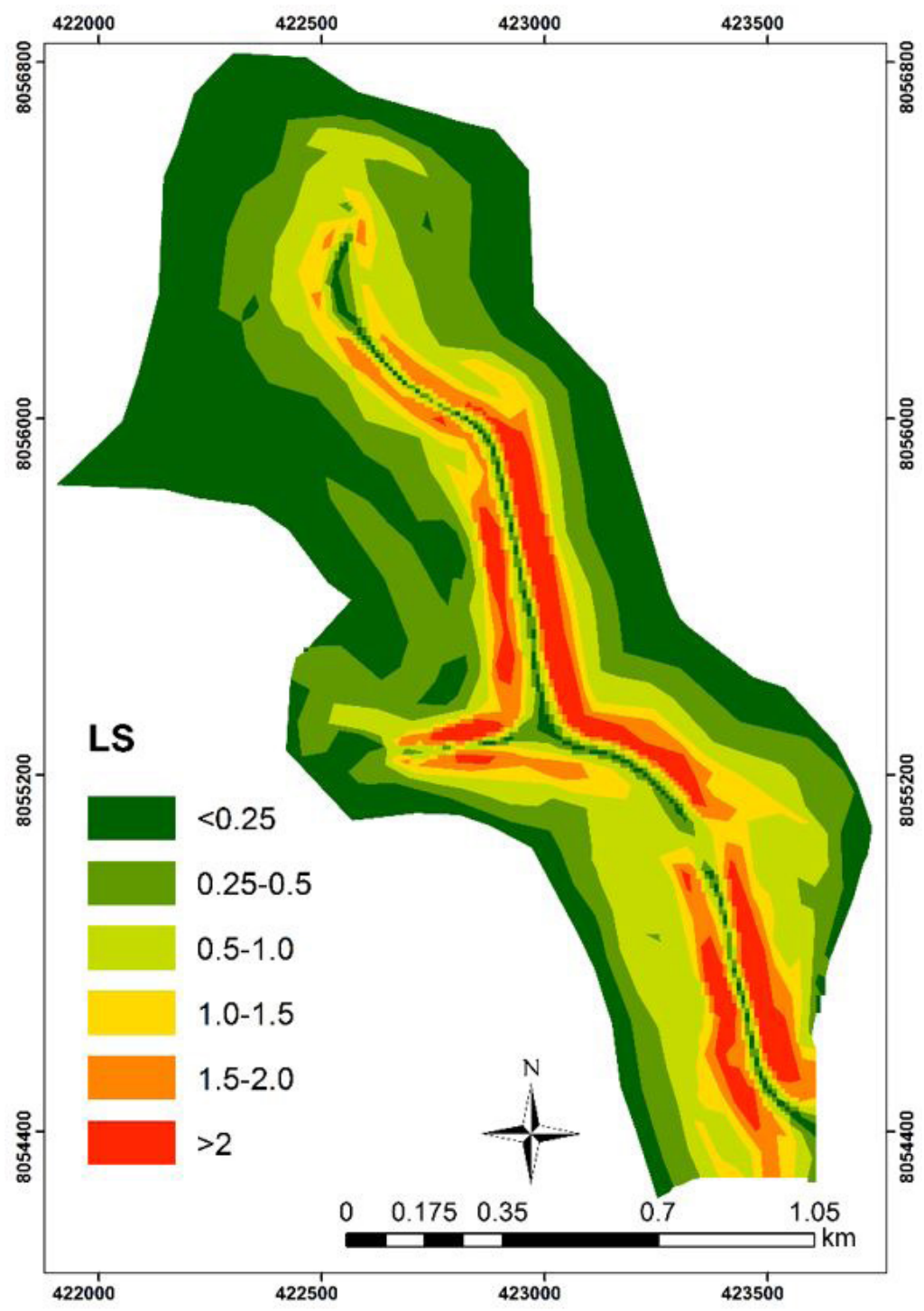

Figure 5. Topographic factor (LS) of the sub-basin in the municipality of Teixeira de Freitas, southern end of the state of Bahia, Brazil. 
of $\mathrm{C}$ reported in this study indicate the good soil cover provided by eucalyptus, despite being a young culture. Martins et al. (2010b) obtained a C factor for eucalyptus and Atlantic Forest of 0.30 and 0.02 , respectively. However, these values result from a seven-year study.

Soil protection against the impact of the raindrops provided by the eucalyptus culture tends to increase gradually as the plant matures due to the increase of the canopy area and the organic matter over the years, forming a thick litter layer. This fact decreases soil loss
(Oliveira et al., 2013) and evidences the importance of maintaining the litter layer.

Spatialization of soil losses for the sub-basin showed a maximum value equivalent to $1,445.6 \mathrm{Mg} \mathrm{ha}^{-1}$ year $^{-1}$. Of the total sub-basin area, $51.1 \%$ had a soil loss value lower than 1 ha $^{-1}$ year-1 $^{-1} 40 \%$ of this total area had soil loss value between 1 and $5 \mathrm{Mg} \mathrm{ha}^{-1}$ year $^{-1} ; 4.6 \%$ of the total area had losses between 5 and $10 \mathrm{Mg} \mathrm{ha}^{-1}$ year $^{-1} ; 1.7 \%$ of the total area had losses between 10 and $100 \mathrm{Mg} \mathrm{ha}^{-1}$ year $^{-1}$; and $2.6 \%$ of the total area had soil losses higher than $100 \mathrm{Mg} \mathrm{ha}^{-1}$ year $^{-1}$ (Figure 6). The areas without vegetation

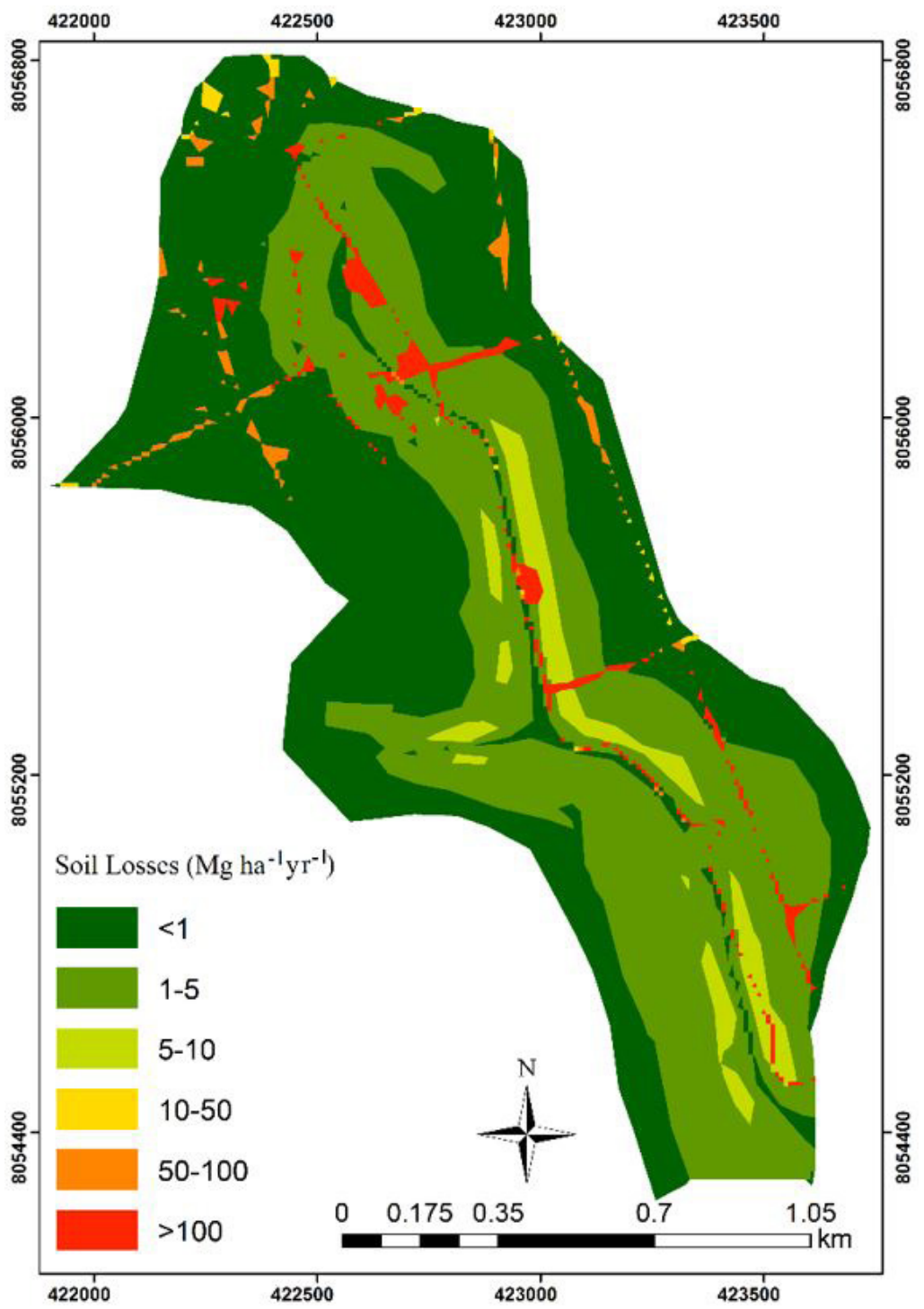

Figure 6. Estimated soil loss for the sub-basin in the municipality of Teixeira de Freitas, southern end of the state of Bahia, Brazil. 
cover and with higher slope steepness presented the highest loss values, which contributed to the formation of runoff particle drag.

Results obtained by soil losses modeling showed that the area covered with eucalyptus had less erosion loss than the native forest area (Table 1). This is because the mean LS of the forest (0.66) is higher than the mean LS value of the eucalyptus forest (0.61).

An overestimation of the values in the areas of eucalyptus and native forest was verified when comparing the soil loss in the plots with that estimated by the USLE. The real soil loss in the uncovered soil area had a maximum value of $155.96 \mathrm{Mg} \mathrm{ha}^{-1}$, while the eucalyptus and native forest areas presented maximum values of $0.04 \mathrm{Mg} \mathrm{ha}^{-1}$ and $0.003 \mathrm{Mg} \mathrm{ha}^{-1}$, respectively.

The overestimation of soil losses by the USLE was also observed by Cabral et al. (2010). The authors explain this result by the fact that the equation does not consider the effect of deposition during the erosive process.

Similarly, Amorim et al. (2010) reported overestimated soil losses using the USLE. According to the authors, this fact is due to the empirical character of the model, which does not consider the temporal precipitation distribution throughout the year.

The soil under eucalyptus presented low soil loss. Considering that eucalyptus is only 18 months old (post-planting period), and its canopy is still underdeveloped when compared with the canopy area of the adult plant, the vegetal cover provided by the species can reduce or prevent soil losses at significant levels, representing only $0.017 \%$ of all soil loss in the uncovered area.

Further studies must be carried out in the region to obtain a complete database, resulting in better adjusted and reliable USLE parameters.

Table 1. Mean soil losses based on data observed in the field and on data obtained from the USLE model.

\begin{tabular}{lcc}
\multirow{2}{*}{ Cover } & \multicolumn{2}{c}{ Soil loss $\left(\mathbf{M g ~ h a}^{-1}\right.$ year $)$} \\
\cline { 2 - 3 } & Observed $^{\star}$ & USLE \\
\hline Eucalyptus & 0.065 & 1.46 \\
Native Forest & 0.013 & 1.58 \\
Uncovered Soil & 378.3 & 350.98 \\
\hline
\end{tabular}

*Annual soil loss in relation to the total soil losses observed in the collection period from October 2012 to March 2014.

\section{CONCLUSIONS}

Rainfall erosivity, in average terms, for the studied period, was $3,438.21 \mathrm{~mm} \mathrm{ha}^{-1} \mathrm{~h}^{-1}$ year ${ }^{-1}$. The soil erodibility factor determined for Yellow Argisol was $0.14 \mathrm{Mg} \mathrm{h} \mathrm{MJ}^{-1} \mathrm{~mm}^{-1}$, while the cover and management factor found for both eucalyptus and native forest was 0.005 .

In vegetated areas, soil losses estimated by the USLE registered higher values than those measured in situ.

The vegetation cover provided by eucalyptus was efficient in reducing soil losses by water erosion, considering that the plant in the present study is still young (18 months).

\section{SUBMISSION STATUS}

Received: 16 oct., 2017

Accepted: 26 oct., 2017

\section{CORRESPONDENCE TO}

\section{Danielle Vieira Guimarães}

Universidade Federal de Lavras - UFLA, Cidade Universitária, Bairro Aquenta Sol, $\mathrm{s} / \mathrm{n}$, CEP 37200-000, Lavras, MG, Brasil e-mail: danyvguimaraes@hotmail.com

\section{FINANCIAL SUPPORT}

National Council for Scientific and Technological Development - CNPq (305010/2013-1, 306511-2017-7, 471522/2012, 202938-2018-2). Coordination for the Improvement of Higher Education Personnel - CAPES (PROEX AUXPE 590/2014, 593/2018). Minas Gerais State Research Foundation - FAPEMIG (PPM-00422-13, CAG-APQ 01053-15, CAG-APQ 00802-18).

\section{REFERENCES}

Amorim RSS, Silva DD, Pruski FF, Matos AT. Avaliação do desempenho dos modelos de predição da erosão hídrica USLE, RUSLE E WEPP para diferentes condições edafoclimáticas do Brasil. Engenharia Agrícola 2010; 30(6): 1046-1049. http://dx.doi.org/10.1590/S010069162010000600006 .

Avanzi JC, Silva MLN, Curi N, Norton LD, Beskow S, Martins SG. Spatial distribution of water erosion risk in a watershed with Eucalyptus and Atlantic Forest. Ciência 
e Agrotecnologia 2013; 37(5): 427-434. http://dx.doi. org/10.1590/S1413-70542013000500006.

Bertoni J, Lombardi F No. Conservação do solo. 8. ed. Piracicaba: Ceres; 2012.

Cabral CEA, Amorim RSS, Dores EFGC, Silva EMB. Estimativa de perda de solo em sistemas de cultivo em lavouras de algodão. Enciclopédia Biosfera 2010; 6: 1-8.

Camargo AP, Sentelhas PC. Avaliação de desempenho de diferentes métodos de estimativa da evapotranspiração potencial no Estado de São Paulo, Brasil. Revista Brasileira de Agrometeorologia 1997; 5: 89-97.

Cecílio RA, Rodriguez RDG, Baena LGN, Oliveira FG, Pruski FF. Aplicação dos modelos RUSLE e WEPP para a estimativa da erosão hídrica em microbacia hidrográfica de Viçosa (MG). Revista Verde 2009; 4: 39-45.

Cogo NP. Uma contribuição à metodologia de estudo das perdas por erosão em condições de chuva natural: alguns conceitos básicos e modelos de uma ficha para registro das características da chuva e perdas de solo e água ( $1^{\mathrm{a}}$ aproximação). In: Anais do $2^{\circ}$ Encontro Nacional de Conservação do Solo; 1978; Passo Fundo. Passo Fundo: Embrapa-CNPT; 1978. p. 99-107.

Eduardo EN, Carvalho DF, Machado RL, Soares PFC, Almeida WS. Erodibilidade, fatores cobertura e manejo e práticas conservacionistas em Argissolo Vermelhoamarelo, sob condições de chuva natural. Revista Brasileira de Ciência do Solo 2013; 37(3): 796-803. http://dx.doi. org/10.1590/S0100-06832013000300026.

Empresa Brasileira de Pesquisa Agropecuária - EMBRAPA. Sistema brasileiro de classificação de solos. 3. ed. Brasília: Embrapa; 2013.

Machado RE, Vetorazzi CA, Xavier AC. Simulação de cenários alternativos de uso da terra em uma microbacia utilizando técnicas de modelagem e geoprocessamento. Revista Brasileira de Ciência do Solo 2003; 27(4): 727-733. http://dx.doi.org/10.1590/S0100-06832003000400017.

Machado RL, Carvalho DF, Rouws JRC, Gomes DP, Eduardo EN. Erosividade das chuvas associada a períodos de retorno e probabilidade de ocorrência no estado do Rio de Janeiro. Revista Brasileira de Ciência do Solo 2013; 37(2): 529-547. http://dx.doi.org/10.1590/S010006832013000200024 .

Martins SG, Avanzi JC, Silva MLN, Curi N, Fonseca S. Erodibilidade do solo nos tabuleiros costeiros. Pesquisa Agropecuária Tropical 2011; 41(3): 322-327. http://dx.doi. org/10.5216/pat.v41i3.9604.

Martins SG, Avanzi JC, Silva MLN, Curi N, Norton LD, Fonseca S. Rainfall erosivity and rainfall return period in the Experimental Watershed of Aracruz, in the Coastal Plain of Espirito Santo. Revista Brasileira de Ciência do Solo 2010a; 34(3): 999-1004. http://dx.doi.org/10.1590/ S0100-06832010000300042.
Martins SG, Silva MLN, Avanzi JC, Curi N, Fonseca S. Fator cobertura e manejo do solo e perdas de solo e água em cultivo de eucalipto e em Mata Atlântica nos Tabuleiros Costeiros do estado do Espírito Santo. Scientia Forestalis 2010b; 38: 517-526.

McCool DK, Brown LC, Foster GR, Mutchler CK, Meyer LD. Revised slope steepness factor for the Universal Soil Loss Equation. Transactions of the ASAE 1987; 30(5): 1387-1396. http://dx.doi.org/10.13031/2013.30576.

McCool DK, Foster GR, Mutchler CK, Meyer LD. Revised slope length factor for the Universal Soil Loss Equation. Transactions of the ASAE 1989; 32(5): 1571-1576. http:// dx.doi.org/10.13031/2013.31192.

McGregor KC, Greer JD, Gurley GE, Bolton GC. Erodibility factors for loring and Lexington soils. Journal of Soil and Water Conservation 1969; 24: 231-232.

Mello CR, Norton LD, Pinto LC, Beskow S, Curi N. Agricultural watershed modeling: a review for hydrology and soil erosion processes. Ciência e Agrotecnologia 2016; 40(1): 7-25. http://dx.doi.org/10.1590/S141370542016000100001 .

Oliveira AH, Silva MA, Silva MLN, Avanzi JC, Curi N, Lima GC et al. Caracterização ambiental e predição dos teores de matéria orgânica do solo na Sub-Bacia do Salto, Extrema, MG. Semina 2012; 33: 143-154.

Oliveira AH, Silva MLN, Curi N, Avanzi JC, Klinke G No, Araújo EF. Water erosion in soils under eucalyptus forest as affected by development stages and management systems. Ciência e Agrotecnologia 2013; 37(2): 159-169. http://dx.doi.org/10.1590/S1413-70542013000200007.

Oliveira PTS, Rodrigues DBB, Alves T So, Panachuk E. Estimativa do fator topográfico da USLE a partir de três algoritmos. Ambiente \& Água 2010; 5(2): 217-225. http:// dx.doi.org/10.4136/ambi-agua.149.

Ozcan AU, Uzun O, Basaran M, Erpul G, Aksit S, Palancioğlu HM. Soil erosion risk assessment for volcano cone of Alidagi mountain by using usle/rusle, gis and geostatistics. Fresenius Environmental Bulletin 2015; 24(6): 2090-2100.

Peel MC, Finlayson BL, McMahon TA. Updated world map of the Köppen-Geiger climate classification. Hydrology and Earth System Sciences 2007; 11(5): 1633-1644. http:// dx.doi.org/10.5194/hess-11-1633-2007.

Rampim L, Tavares J Fo, Behlau F, Romano D. Determinação da capacidade de uso do solo visando o manejo sustentável para uma média propriedade em Londrina-PR. Bioscience Journal 2012; 28: 251-264.

Renard KG, Foster GR, Weesies GA, McCool DK, Yoder DC. Predicting soil erosion by water: a guide to conservation planning with the Revised Universal Soil Loss Equation (RUSLE). Washington: Department of Agriculture; 1997.

Ribeiro AS, Mincato RL, Curi N, Kawakubo FS. Vulnerabilidade ambiental à erosão hídrica em uma subbacia hidrográfica pelo processo analítico hierárquico. 
Revista Brasileira de Geografia Física 2016; 9: 16-31. http:// dx.doi.org/10.5935/1984-2295.20160001.

Santos VS, Oliveira OJ, Moreira MAA, Lorandi R. Análise e espacialização das perdas médias de solo por erosão hídrica laminar na bacia hidrográfica do Tenente Amaral em Jaciara, Mato Grosso, Brasil. In: Anais do $1^{\circ}$ Simpósio de geotecnologias no Pantanal; 2006; Campo Grande. Campo Grande: Embrapa Informática Agropecuária/ INPE; 2006. p. 247-256.

Silva BPC, Silva MLN, Batista PVG, Pontes LM, Araújo EF, Curi N. Soil and water losses in eucalyptus plantation and natural forest and determination of the USLE factors at a pilot sub-basin in Rio Grande do Sul, Brazil. Ciência e Agrotecnologia 2016; 40(4): 432-442. http://dx.doi. org/10.1590/1413-70542016404013216.

Silva E, Curi N, Ferreira MM, Volpato MML, Santos WJR, Silva SHG. Pedotransfer functions for water retention in the main soils from the brazilian coastal plains. Ciência e Agrotecnologia 2015; 39(4): 331-338. http://dx.doi. org/10.1590/S1413-70542015000400003.

Silva MA, Freitas DAF, Silva MLN, Oliveira AH, Lima GC, Curi N. Sistema de informações geográficas no planejamento de uso do solo. Agrária 2013; 8(2): 316-323. http://dx.doi.org/10.5039/agraria.v8i2a2289.

Trindade ALF, Oliveira PTS, Anache JAA, Wendland E. Variabilidade espacial da erosividade das chuvas no Brasil. Pesquisa Agropecuária Brasileira 2016; 51(12): 1918-1928. http://dx.doi.org/10.1590/s0100-204x2016001200002.

Wischmeier WH. Cropping-management factor for a universal soil-loss equation. Soil Science Society of America Journal 1960; 24(4): 322-326. http://dx.doi.org/10.2136/ sssaj1960.03615995002400040032x.

Wischmeier WH, Smith DD. Predicting rainfall erosion losses: a guide to conservation planning. Washington: USDA; 1978. (Agricultural Handbook; no. 537). 